\section{'Dorada' Apricot}

\section{J. Egea, ${ }^{1}$ D. Ruiz, and L. Burgos \\ Departamento de Mejora Vegetal, Centro de Edafología y Biología Aplicada del Segura-Consejo Superior de Investigaciones Cientificas, P.O. Box 164, E- 30100, Espinardo, Murcia, Spain}

Additional index words. fruit breeding, Prunus armeniaca, self-compatibility, fruit quality, canning aptitude

'Dorada' is a late ripening apricot cultivar (Prunus armeniaca L.) with high productivity, good fruit quality and an attractive light-orange fruit suitable for the European markets. This cultivar is well adapted to the climatic conditions at the mountains of Spain. 'Dorada' is self-compatible and possesses a high degree of autogamy. 'Dorada' fruit are free stone with a light orange skin color and a yellow-light orange flesh color that make them very attractive. This cultivar is also characterized by its good aptitude for canning.

\section{Origin}

'Dorada' resulted from a cross made in 1992 at Murcia (Spain) between the French cultivar, of unknown origin, 'Bergeron', and the Spanish cultivar, of unknown origin, 'Moniquí' (Fig. 1). This cross was made within the apricot breeding program at CEBAS-CSIC in Murcia (Spain) with the objective of obtaining good fruit quality as well as canning aptitude.

\section{Description}

Tree description. 'Dorada' was originally selected as a seedling tree on its own roots and then grafted onto apricot seedlings (3 repetitions). Trees of 'Dorada' are large and medium vigorous with a moderate spread. It has a moderate density of flowers (22.9 flow$\mathrm{ers} / \mathrm{cm}^{2}$ of shoots) mainly localized on fruiting spurs of two-year-old branches. Flower density was calculated from the number of flowers on productive shoots, which were about $1.2 \mathrm{~m}$. long and where basal diameter was measured. Flower density was expressed as flowers $/ \mathrm{cm}^{2}$ of shoot basal section, average of three repetitions. 'Dorada' cultivar showed a very high fruit set $(50.5 \%)$ (Table 1$)$, this parameter being calculated in the same shoots as flower density by counting the fruit and dividing by the number of flowers. 'Dorada' is characterized by large fruit and very high productivity in comparison

Received for publication 6 Apr. 2005. Accepted for publication 18 June 2005. We thank Pedro MartínezGómez, Adela Martínez and José Luis Patiño for technical assistance in obtaining this cultivar. The work has been financed with several projects of the Plan Nacional de I+D of the Spanish Ministry of Science and Technology from 1985, the last one being titled Mejora Genética del Albaricoquero (AGL2001-112-C02-01). The authors dedicate this paper to Luis Egea, who dedicated a great part of his life to the apricot breeding program of the CEBAS-CSIC

'Corresponding author; email agr007@cebas.csic.es. with traditional Spanish apricot cultivars. Tree architecture greatly facilitates pruning (reduced branching habit)

$P P V$ resistance. Sharka disease caused by the plum pox virus (PPV) is a serious limiting factor for temperate fruit production in those areas that are affected (Kölber, 2001). All apricot cultivars traditionally grown in Europe are susceptible to this disease (Martínez-Gómez et al., 2000). Evaluation of PPV resistance in controlled greenhouse conditions (MartínezGómez and Dicenta, 1999) has not been tested in 'Dorada' because none of their parents are known as resistant varieties.

Time of bloom. 'Dorada' has medium-high chilling requirements for breaking dormancy, about 1,050 \pm 70 chill units (Richardson et al., 1974). The growing degree hour (GDH) requirements (Richardson et al., 1975) between the end of the rest period and full bloom were $5000 \pm 500$. Under our experimental conditions in Murcia (southeast of Spain, $37^{\circ} \mathrm{N}$ latitude, $1^{\circ} \mathrm{W}$ longitude, and $450 \mathrm{~m}$ altitude) 'Dorada' full bloom occurred about 14 Mar. $( \pm 4 \mathrm{~d}$ as average from 3 years), a medium-late flowering date among traditional Spanish apricot cultivars (Table 1).

Self-compatibility and autogamy. Fruit set percentage averaged $50.5 \% \pm 3 \%$ over 3 years. The self-compatibility of this cultivar was

Dorada $-\left[\begin{array}{c}\text { Bergeron } \\ \text { (French cultivar) } \\ \text { Moniquí } \\ \text { (Spanish cultivar) }\end{array}\right.$

Fig. 1. Pedigree of 'Dorada' apricot.

Table 1. Comparative analysis of tree and fruit characteristics of 'Dorada', the Spanish cultivar 'Búlida', the French cultivar 'Bergeron', and the North American cultivar 'Orange Red'.

\begin{tabular}{lcccc}
\hline Characteristics & 'Dorada' & 'Búlida' & 'Bergeron' & 'Orange Red' \\
\hline Tree & & & & \\
$\quad$ Vigour & Vigorous & Very vigorous & Very vigorous & Vigorous \\
Flower density (flower/cm $\left.{ }^{2}\right)$ & 22.9 & 42.0 & 31.1 & 5.1 \\
$\quad$ Flowering date (full bloom) & $14 \mathrm{Mar}$. & $8 \mathrm{Mar}$. & $13 \mathrm{Mar}$. & $15 \mathrm{Mar}$. \\
$\quad$ Fruit set $(\%)$ & 50.5 & 31.6 & 39.4 & 13.6 \\
$\quad$ Yield & Very high & High & High & Medium \\
Fruit & & & & \\
$\quad$ Ripening date & 22 June & $26 \mathrm{May}$ & $19 \mathrm{June}$ & $28 \mathrm{May}$ \\
Fruit size $(\mathrm{g})$ & 73.1 & 59.8 & 70.7 & 61.0 \\
Attractiveness & 8.3 & 6.7 & 7.2 & 9.0 \\
Sugar $\left({ }^{\circ}\right.$ Brix) & 13.1 & 10.62 & 11.90 & 14.22 \\
Acidity & 1.24 & 1.29 & 1.73 & 1.23 \\
\hline
\end{tabular}

${ }^{\mathrm{z}}$ Titratable acidity expressed as grams of malic acid per $100 \mathrm{~mL}$. Red' and the Spanish cultivar 'Búlida'. This demonstrated in the field (by bagging branches) and in the laboratory (by observing pollen tube growth infiveflowers). The natural autogamy of 'Dorada' was assessed by bagging branches just before anthesis and recording the fruit set.

Fruit size, firmness, and color. Fruit harvested from the original own-rooted seedling tree and from trees of 'Dorada' grafted onto apricot seedlings (three replications) were studied over 3 years. 'Dorada' trees and reference variety trees ('Búlida', 'Orange Red', and 'Bergeron') were cultivated in the same orchard according to habitual apricot orchard management. Fruit characterization of 'Dorada' apricot and reference varieties was made at commercial maturity. 'Dorada' bears large and globose fruit with an average weight of about $73 \mathrm{~g}$, an axial diameter of $4.9 \mathrm{~cm}$, a transverse diameter in suture plane of $5.0 \mathrm{~cm}$, and a transverse diameter at right to suture plane of $5.3 \mathrm{~cm}$ (Fig. 2) 'Dorada' fruit are also characterized as firm $\left(1.72 \pm 0.3 \mathrm{~kg} \cdot \mathrm{cm}^{-2}\right)$ at commercial ripeness, with low skin cracking, and a free stone without pit burning problems. Fruit have light orange skin color (Hue value $=80.8 \pm 2.3$, with color space coordinates $\mathrm{L}^{*}=69.65, \mathrm{a}^{*}=8.05, \mathrm{~b}^{*}$ $=50.28$, in chromameter (CR-300; Minolta, Ramsey, N.J.) with a yellow-light orange flesh color (Hue value $=82.1 \pm 2.6$, with color space coordinates $\mathrm{L}^{*}=71.31, \mathrm{a}^{*}=6.92, \mathrm{~b}^{*}=49.4$ ). The attractiveness of 'Dorada' fruit by subjective evaluation of 4 people reached 8.3 on average in a scale between 0 and 10 (Table 1).

Organoleptic characteristics. At the commercial-maturity stage 'Dorada' fruit are sweet $\left(13.1^{\circ}\right.$ Brix on average $)$ with low acidity $(1.24 \mathrm{~g}$ malic acid $/ 100 \mathrm{~mL}$ on average) and a very good eating quality (Table 1). 'Dorada' fruit have a mild apricot aroma.

Maturation time. Fruit of 'Dorada' mature uniformly. In our experimental conditions in Murcia, 'Dorada' matures about 22 June, 25 d later than the North American cultivar 'Orange cultivar showed a late maturation in comparison with the traditional Spanish apricot cultivars (Table 1).

Canning aptitude. Canning aptitude has been tested in 'Dorada' fruit in the National Research Institute for Canned Goods (Murcia, Spain). Syrup, pulp and puree from 'Dorada' fruit showed very good characteristics concerning color, texture and flavor, as well as relating to conservation. 


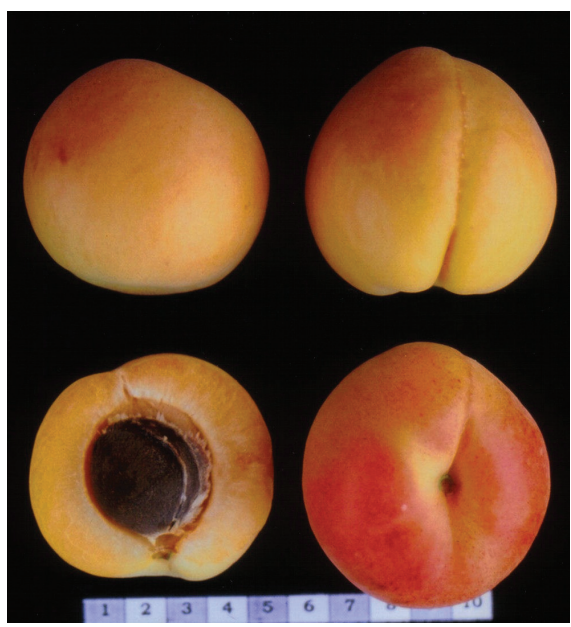

Fig. 2. Fruit of 'Dorada' apricot. Scale bar in centimeters.

\section{Molecular Characterization}

Simple sequence repeat (SSR) analysis. Eleven SSR markers previously developed in peach were screened for polymorphism of 'Dorada' apricot DNA. Seven SSR markers were able to distinguish 'Dorada' and its progenitors. The DNA fingerprints of 'Dorada' and its progenitors 'Bergeron' and 'Moniquí' are shown in Table 2.

\section{Availability}

Virus-free budwood is available from CEBAS-CSIC (Spain). This cultivar is registered in the European Union Community Plant Variety Office with the registration number 2003/1216. Budwood has been tested and is free of the following viruses: prunus necrotic ring spot virus (PNRSV), apple mosaic virus (ApMV), apple clorotic leaf spot virus (ACLSV), prune dwarf virus (PDV), and plum pox virus (PPV).

\section{Literature Cited}

Aranzana, M.J., J. García-Mas, J. Carbó, and P. Arús. 2002. Development and variability analysis of microsatellite markers in peach. Plant Breed. 121:87-92.

Cipriani, G., G. Lot, H.G. Huang, M.T. Marrazzo, E.

Table 2. Molecular characterization of 'Dorada' apricot cultivar and its parents 'Bergeron' and 'Moniquí' using peach simple sequence repeat (SSR) markers.

\begin{tabular}{llccc}
\hline & & \multicolumn{3}{c}{ Size of amplified bands (bp) } \\
\cline { 3 - 5 } SSR marker & Reference & $203 / 203$ & $203 / 203$ & $203 / 212$ \\
\hline BPPCT 017 & Dirlewanger et al., 2002 & $238 / 257$ & $238 / 238$ & $257 / 257$ \\
CPPCT 022 & Aranzana et al., 2002 & $93 / 93$ & $93 / 115$ & $93 / 93$ \\
UDP 96003 & Cipriani et al., 1999 & $128 / 128$ & $128 / 138$ & $128 / 128$ \\
UDP 96008 & Cipriani et al., 1999 & $170 / 214$ & $170 / 214$ & $170 / 170$ \\
UDP 96019 & Cipriani et al., 1999 & $95 / 95$ & $95 / 95$ & $95 / 100$ \\
UDP 98406 & Cipriani et al., 1999 & $96 / 114$ & $110 / 114$ & $96 / 110$ \\
UDP 98412 & Testolin et al., 2000 & &
\end{tabular}

Peterlunger, and R. Testolin. 1999. AC/GT and AG/CT microsatellite repeats in peach (Prunus persica (L) Basch): Isolation, characterization and cross-species amplification in Prunus. Theor. Appl. Genet. 99:65-72.

Dirlewanger, E., A. Crosson, P. Tavaud, M.J. Aranzana, C. Poizat,A. Zanetto, P. Arús, and L. Laigret. 2002. Development of microstellite markers in peach and their use in genetic diversity analysis in peach and sweet cherry. Theor. Appl. Genet. 105:127-138.

Kölber, M. 2001. Workshop on plum pox. Acta Hort. 550:249-255.

Martínez-Gómez, P. andF. Dicenta. 1999. Evaluation of resistance to sharka in the breeding apricot program in CEBAS-CSIC in Murcia (Spain). Acta Hort. 488:731-737.

Martínez-Gómez, P., F. Dicenta, and J.M. Audergon. 2000. Behaviour of apricot (Prunus armeniaca L.) cultivars in the presence of sharka (plum pox potyvirus): A review. Agronomie 20:407-422 .

Richardson, E.A., S.D. Seeley, and R.D. Walker. 1974. A model estimating the completion of rest for Red Haven and Elberta peach. HortScience 9:331-332.

Richardson, E.A., S.D. Seeley, R.D. Walker, J.L. Anderson, and G.L. Ashcroft. 1975. Pheno-climatography of spring peach bud development. HortScience 10:236-237.

Testolin, R., T. Marrazo, G. Cipriani, R. Quarta, I. Verde, M.T. Dettori, M. Pancaldi, and S. Sansavini. 2000. Microsatellite DNA in peach (Prunus persica L. Batsch) and its use in fingerprinting and testing the genetic origin of cultivars. Genome 43:512-520. 